OPEN ACCESS

Edited by:

Terry Engle,

Colorado State University

United States

Reviewed by:

Jorge Avila Stagno,

University of Concepcion, Chile

F. Capela e Silva

University of Evora, Portugal

Yosra Ahmed Soltan,

Alexandria University, Egypt

${ }^{*}$ Correspondence:

Marcela Šperanda

marcela.speranda@fazos.hr

Specialty section:

This article was submitted to Animal Nutrition and Metabolism,

a section of the journal

Frontiers in Veterinary Science

Received: 31 March 2021 Accepted: 29 June 2021 Published: 30 July 2021

Citation:

Šperanda T, Pavić V, Lončarić Z, Šperanda M, Popović M, Gantner V and Eidara M (2021) Selenium and

Natural Zeolite Clinoptilolite

Supplementation Increases Antioxidative Status and Immune

Response in Growing Pigs. Front. Vet. Sci. 8:688915 doi: 10.3389/fvets.2021.688915

\section{Selenium and Natural Zeolite Clinoptilolite Supplementation Increases Antioxidative Status and Immune Response in Growing Pigs}

\author{
Tomislav Šperanda ${ }^{1}$, Valentina Pavić ${ }^{2}$, Zdenko Lončarić ${ }^{1}$, Marcela Šperanda ${ }^{1 *}$, \\ Maja Popović ${ }^{3}$, Vesna Gantner ${ }^{1}$ and Mislav Đidara ${ }^{1}$ \\ ${ }^{1}$ Faculty of Agrobiotechnical Science in Osijek, J. J. Strossmayer University of Osijek, Osijek, Croatia, ${ }^{2}$ Department of \\ Biology, J. J. Strossmayer University of Osijek, Osijek, Croatia, ${ }^{3}$ Veterinary Faculty, University of Zagreb, Zagreb, Croatia
}

Selenium (Se), an essential trace element for human and animal health, is covalently incorporated into amino acids, acts as a cofactor for antioxidant enzymes, and is involved in the maintenance of the immune system. The main goal of this investigation was to show the effect of Se supplementation, at levels slightly higher than the recommended values, combined with natural zeolite clinoptilolite on Se deposition in tissues (muscle and liver) and on the immune and antioxidative status of supplemented growing pigs. The experiment was carried out during a $98 \mathrm{~d}$ period on 60 pigs. Pigs were fed a standard feed mixture based on corn and soybean and were divided into four groups, according to the level of dietary selenium supplementation as follows: C-0.3 mg/kg DM organic Se, E1-0.5 $\mathrm{mg} / \mathrm{kg}$ DM sodium selenite, E2-0.5 mg/kg DM organic selenium; E3-0.5 mg/kg DM organic Se+0.2\% zeolite. Higher $(P<0.05)$ selenium concentrations were determined in the muscle and liver in growing pigs fed with higher organic Se in combination with zeolite compared to the lower organic Se concentration. Addition of organic Se increased $(P<0.05)$ Se deposition in muscle and liver compared to the equal amount of inorganic Se (E2 vs. E1). Higher organic Se in combination with natural zeolite addition increases $(P<0.05)$ proportion of pigs' cluster of differentiation $(C D) 45^{+}$compared to the same amount of inorganic Se and lower organic Se addition. The proportion of CD45 ${ }^{+}$and CD4 ${ }^{+}$lymphocytes was higher $(P<0.05)$ in E3 group compared to the other groups. Higher $(P<0.05)$ proportion of $\mathrm{CD} 21^{+}$lymphocytes were measured in the E2 and E3 groups compared with the other groups. The highest $(P<0.01)$ activity of glutathione peroxidase (GSH-Px) in pig erythrocytes was observed in the E3 group, while higher $(P<0.05)$ activity of glutathione reductase $(\mathrm{GR})$ was in all experimental groups related to the control one. A dietary addition of $0.5 \mathrm{mg} / \mathrm{kg}$ DM of organic Se in combination with zeolite $(0.2 \% \mathrm{DM})$ has increased $(P<0.05)$ Se deposition in liver, muscle, and blood, compared to the dietary addition of $0.3 \mathrm{mg} / \mathrm{kg}$ DM of the organic Se.

Keywords: antioxidative status, immune response, natural zeolite clinoptilolite, selenium deposition, selenium supplementation 


\section{INTRODUCTION}

Selenium (Se) is an essential element for humans and animals but not for plants (1). The bioavailability of Se depends on the plant itself as well as on the concentration of Se in the soil $(2,3)$. Selenium concentrations in three main soil types of the main agricultural region of Croatia (Osijek-Baranja County), namely haplic gelysol, stagnosol, and luvisol, were reported to be 538, 323 , and $314 \mu \mathrm{g} / \mathrm{kg}$, respectively (4), which means that there is a demand for Se supplementation in animal nutrition (5). As a key component of glutathione peroxidase (GSH-GPx) and other selenoproteins, Se is essential and plays a crucial role in various biological processes, such as the fertilization capacity of spermatozoa (6), semen quality and fertility under heat stress conditions (7), innate and adaptive immune responses (8), metabolic rate (9), and reduced accumulation of heavy metals in tissues (10). Many studies have attempted to produce Se-enriched animal products via feed-based nutritional interventions to increase Se deposition in meat, eggs, and milk (11). Therefore, Se-enriched animal products have drawn extensive attention due to their potential to improve the Se health status of human consumers $(12,13)$. Supplementation of animal feed with the mineral form of Se, also named inorganic form of Se, has some disadvantages, which are related to an interaction with other minerals, relative high toxicity, and inability to build and maintain Se reserves in the body (8). Furthermore, selenite at high doses has been reported to act as a pro-oxidant. It has been suggested that organic selenium is more effective because it reaches tissues more efficiently and therefore the use of organic Se sources, such as selenomethionine has been shown to be superior to that of inorganic sources (14). Zavodnik et al. (15) have demonstrated a 6-percent birth rate increase concerning the piglets fed by Se yeast supplement, an increase in saw litter weight to $11.1 \%$ and the concentration of Se in muscle increased up to $27.8 \%$. In post-weaning piglets, an increase in liver and plasma selenium concentrations subsequent to a supplementation with Se from both organic and inorganic sources. Interestingly, the plasma activity of GSH-Px has been found to decrease with the increase in Se supplementation, but the hepatic activity of GSHPx increases with increasing Se supplementation, regardless of the type of source (16). According to Rovers (17), Se deposition in muscle tissue is a good indicator of the selenium status of animals. The same author strongly suggests that selenized yeast with higher concentrations of selenomethionine significantly increases deposition of $\mathrm{Se}$ in muscle tissue compared with selenized yeast with a lower content of selenomethionine.

Natural zeolite clinoptilolite has been used in veterinary and human medicine as feed ingredient due to its beneficial properties as immunostimulant (18) or as an adjuvant in antibiotics delivery (19). One explanation of beneficial immune effects of silica, silicates, and aluminosilicates could be their action as nonspecific superantigen-like immunoglobulins (SAg) capable of activating a large population of T-cells. The activation occurs as a result of a simultaneous interaction between SAg, T cell receptor (TcR) variable region $\beta$, and major histocompatibility complex (MHC) class II molecules on the surface of antigen presenting cells (APC) (20). In the weaned piglets which have received $0.5 \%$ clinoptilolite for 5 weeks, it was observed that the clinoptilolite was effective as an immunomodulatory agent by promoting the recruitment of circulating and intestinal immune cell subsets, even though it has not improved the growth in the weaned pigs, and generally failed to improve their feed conversion efficiency (21). These findings encouraged us to investigate the combined effect of higher Se concentrations and natural zeolite clinoptilolite on Se deposition in pig tissues (muscle and liver) as well as on the immune and antioxidative status of the supplemented animals.

The hypothesis is based on a knowledge that selenium and zeolite, separately, enhance an immune response and exert an antioxidant effect. It was our assumption that a higher amount of organic Se source $(0.5 \mathrm{mg} / \mathrm{kg} \mathrm{DM})$ in combination with a natural zeolite clinoptilolite, will result in a better tissue deposition when compared with the same amount of inorganic Se and a lower amount of an organic Se source $(0.3 \mathrm{mg} / \mathrm{kg} \mathrm{DM})$.

\section{MATERIALS AND METHODS}

\section{Animals, Feeding, and Experimental Design}

The experiment was carried out on commercial pig farm randomly distributing 60 animals (crossbred Large White $\times$ Swedish Landace $\times$ Pietrain) to four different boxes with full concrete floor and Big Dutchman ${ }^{\circledR}$ feeders. Animals (initial body weight $30.85 \pm 0.30 \mathrm{~kg}$ ) were fed over a period of 98 days with a standard feed mixture based on corn and soybean for fattening up to $60 \mathrm{~kg}$ (ST-1; Se concentration $0.058 \mathrm{mg} / \mathrm{kg} \mathrm{DM}$ ) and a mixture for fattening up to $100 \mathrm{~kg}$ (ST-2, Se concentration $0.050 \mathrm{mg} / \mathrm{kg}$ DM; Table 1). The groups were fed different dietary selenium treatments as follows: C- $0.3 \mathrm{mg} / \mathrm{kg}$ DM organic Se, E1-0.5 mg/kg DM sodium selenite, E2-0.5 mg/kg DM organic selenium; E3-0.5 mg/kg DM organic Se+0.2\% natural zeolite clinoptilolite (Zeotex; Mevex Ltd, Zagreb, Croatia; Table 2). The dietary treatment with $0.3 \mathrm{mg} / \mathrm{kg} \mathrm{DM}$ organic Se in C was used as a standard recommended by NRC (22) $(0.3 \mathrm{mg} / \mathrm{kg}$ for weaning pigs to $0.15 \mathrm{mg} / \mathrm{kg}$ for growing pigs). Because of the lack of Se in the soil, and consequently in plants, the current regulation allows up to $0.3 \mathrm{mg} / \mathrm{kg}$ of Se in the diet for all pigs, hence that level was used in our research as a gold standard. Feed and water were offered ad libitum, with an average ambient temperature of $25^{\circ} \mathrm{C}$ during the day and $16^{\circ} \mathrm{C}$ during the night. Pigs were weighted at the beginning of the trial, 50th and 98th day. The trial was conducted according to Directive 2010/63/EU of the European Parliament (2010) on the protection of animals used for scientific purposes, according to Croatian Animal Protection Act, other legal acts regarding the animal welfare and with Approval of Bioethics Committee for Research on Animals University in Osijek (2158-94-02-21-02).

\section{Chemical Composition of the Diets}

The feed composition was determined using standard methods (AOAC, 2006). Feed samples were analyzed for dry matter $\left(24 \mathrm{~h}\right.$ at $103^{\circ} \mathrm{C}$; ISO 6496:2001) and ash by ISO 5984:2002. The crude protein $(\mathrm{CP})$ content was estimated from the nitrogen concentration according to the Kjeldahl method using Kjeldahl 
TABLE 1 | Ingredients and chemical composition of the experimental diets.

\begin{tabular}{|c|c|c|}
\hline Ingredient & ST - 1 & ST - 2 \\
\hline & $\%$ & $\%$ \\
\hline Dry corn & 30 & 30 \\
\hline Wet corn & - & 20 \\
\hline Barley & 33 & 26 \\
\hline Bran & 8 & 5.5 \\
\hline Soybean meal & 7 & 11 \\
\hline Extruded soybean & 10 & - \\
\hline Sunflower meal & - & 5 \\
\hline Sunflower cake & 9 & - \\
\hline Calcium carbonate & 1.5 & 1 \\
\hline Monocalcium phosphate & 1 & 1 \\
\hline Mineral premix ${ }^{\star}$ & 0.5 & 0.5 \\
\hline Total & 100 & 100 \\
\hline \multicolumn{3}{|c|}{ Chemical composition } \\
\hline Dry matter & 87.50 & 87.50 \\
\hline Crude protein & 16.10 & 13.90 \\
\hline Fat & 3.70 & 3.30 \\
\hline Crude fiber & 5.30 & 6.90 \\
\hline Ash & 4.93 & 5.84 \\
\hline $\mathrm{Na}$ & 0.14 & 0.13 \\
\hline $\mathrm{Ca}$ & 0.63 & 0.66 \\
\hline $\mathrm{P}$ & 0.45 & 0.40 \\
\hline $\mathrm{Se}$ & 0.0588 mg/kg DM & $0.0507 \mathrm{mg} / \mathrm{kg} \mathrm{DM}$ \\
\hline
\end{tabular}

"Mineral premix: Iron 16,000 mg, Copper 4,000 mg, Manganese 8,000 mg, Zink $16,000 \mathrm{mg}$, lodine $150 \mathrm{mg}$, Cobalt 40 mg, vitamin A 1,000,000 IU, vitamin D3 100,000 IU, vitamin E 2,400 mg, vitamin K3 $400 \mathrm{mg}$, vitamin B1 $400 \mathrm{mg}$, vitamin B2 $600 \mathrm{mg}$, vitamin B6 400 mg, vitamin B12 3 mg, Nicotine acid 3,000 mg, Pantothenic acid 2,000 mg, Colin chloride $100,000 \mathrm{mg}$.

TABLE 2 | Selenium supplementation and experimental design.

\begin{tabular}{lll}
\hline Group & $\boldsymbol{N}$ & Supplementation \\
\hline Control & 20 & $0.3 \mathrm{mg}$ organic selenium \\
E1 & 20 & $0.5 \mathrm{mg}$ inorganic selenium \\
E2 & 20 & $0.5 \mathrm{mg}$ organic selenium \\
E3 & 20 & $0.5 \mathrm{mg}$ organic selenium $+0.2 \%$ clinoptilolite
\end{tabular}

*Zeolite clinoptilolite composition: $\mathrm{SiO}_{2} 63-68 \%, \mathrm{Al}_{2} \mathrm{O}_{3} 11-14 \%, \mathrm{Fe}_{2} \mathrm{O}_{3}$ 0.8-2.5\%, MnO $0.01-0.3 \%, \mathrm{CaO} 2.5-4.5 \%, \mathrm{MgO} 0.8-1.5 \%, \mathrm{Na}_{2} \mathrm{O} 0.8-1.5 \% \mathrm{~K}_{2} \mathrm{O} 1-2 \%$ L.I. $10.5-14.5 \%$.

steam distillation for nitrogen (Behr, Stuttgart, Germany; ISO 5983-2:2005). The Universal Extraction System B-811 (Buchi, Flawil, Switzerland) was used to analyze ether extract (EE; ISO 6492:1999). The ingredients and chemical compositions of the experimental diets are shown in Table 1. Selenium supplementation was added according to the experimental model, as shown in Table 2.

\section{Sample Collection}

Blood samples were collected from $v$. cava cranialis in vacuum tubes with heparin as an anticoagulant (Beckton Dickinson, Plymouth, UK) for selenium concentration and antioxidative enzymes. Other samples were taken with the EDTA for flow cytometry at $10 \mathrm{a} . \mathrm{m}$. at each sampling point on eight pigs from each group. To measure selenium concentration in blood, immune parameters, and enzymes in antioxidant status blood samples were collected at the beginning of the trial (day 0) and at the 50th, 71st, and 98th days of trial. The samples of the $m$. longissimus dorsi and liver were taken at the end of the trial, subsequent to slaughter, at the abattoir, for the determination of selenium concentration. A piece of $\sim 7 \mathrm{~cm}$ from the left longissimus dorsi muscles were excised, starting at the joint between 12th and 13th thoracic vertebrae. A liver sample was taken from the apex of the left medial lobe (lobus hepatis sinister medialis).

\section{Determination of Selenium Concentration in Blood, Muscle, and Liver Tissue by ICP-OES}

The concentration of selenium in blood, muscle, and liver tissue was determined using inductively coupled plasma optical emission spectrometry (ICP-OES, PerkinElmer Optima 2100 DV, USA). For the pre-reduction of Se, $20 \mathrm{~mL}$ of samples were placed in a clean $50 \mathrm{~mL}$ beaker, and $20 \mathrm{~mL}$ of concentrated $\mathrm{HCl}$ was added to reduce $\mathrm{Se}^{6+}$ to $\mathrm{Se}^{4+}(12)$. The mixture was heated to $90^{\circ} \mathrm{C}$ and cooled to room temperature. The wavelength for Se determination was $196.026 \mathrm{~nm}$. For the quality control of the analytical method, the certified reference material, Cabbage (NCS ZC 73012, China National Analysis Center) was digested, and the total concentration was determined for method validation. The recovery rates of Se were within the range of $10 \%$. All samples were analyzed in triplicate.

\section{Determination of Circulating Immune Cell Subsets by Flow Cytometry}

The monoclonal antibodies (mAbs) reactive with swine leukocyte surface molecules (i.e., cluster of differentiation [CD] antigens) that we used for the identification and quantification of patterns of the lymphoid cell subsets are listed in Table 3. Anti-swine $\mathrm{mAbs}$ to $\mathrm{CD}_{4}{ }^{+}$(clone K252-1E4), $\mathrm{CD}^{+}$(clone 74-12-4), $\mathrm{CD}^{+}$(clone 76-2-11), and $\mathrm{CD}^{+} 1^{+}$molecules (clone BB611C9.6) were obtained from Abcam (Cambridge, UK). The cell suspensions were prepared and incubated with mAbs (50 $\mu 1 / 10^{6}$ cells) in single color flow cytometry to determine the percentage of positively stained cells (23). Flow cytometric analysis of the positively stained cells expressing $\mathrm{CD} 45^{+}, \mathrm{CD} 4^{+}$, $\mathrm{CD}^{+}$, or $\mathrm{CD} 21^{+}$molecules were performed for each animal, and the data are presented as the arithmetic mean \pm pooled standard error of mean (mean \pm SEM). The fluorescence of the mAb-labeled porcine lymphoid cells was quantified using a Coulter EPICS-XL flow cytometer (Beckman Coulter Miami FL, USA) as reported earlier (24). The isotype-matched mouse immunoglobulins were used to detect non-specific fluorescence in control cell suspensions.

\section{Determination of Antioxidative Enzymes: GSH-Px and Glutathione Reductase (GR)}

For antioxidative enzyme determination, blood was centrifuged for $5 \mathrm{~min}$ at $1,500 \mathrm{~g}$. After removing the plasma and buffy coat, 
TABLE 3 | Murine monoclonal antibodies specific to swine leukocyte surface CD (cluster of differentiation) antigens and conjugates used in cytometric immunophenotyping of peripheral blood lymphoid cells from growing pigs fed with different Se sources and concentrations.

\begin{tabular}{lllll}
\hline Clone $(\mathbf{m A b}) \mathbf{p A b}$ & Isotype & mAb specificity & Conjugate & Targeted cells/molecule \\
\hline $74-12-4$ & lgG2b & $\mathrm{CD} 4^{+}$ & Pe/Cy5 ${ }^{\circledR}$ & Helper T lymphocytes \\
$76-2-11$ & IgG2a & $\mathrm{CD} 8^{+}$ & Phycoerythrrine & Cytolytic T lymphocytes \\
K252-1E4 & lgG1 & $\mathrm{CD} 45^{+}$ & FITC & Lymphoid cells \\
BB6-11C9.6 & lgG1 & $\mathrm{CD} 21^{+}$ & FITC & B lymphocytes \\
\hline
\end{tabular}

TABLE 4 | Average body weight $(\mathrm{kg})$ of growing pigs fed different Se source and concentration with $P$-values of effects tested in statistical model.

\begin{tabular}{|c|c|c|c|c|c|c|c|c|}
\hline \multirow[b]{2}{*}{ Day } & \multicolumn{4}{|c|}{ Group } & \multirow[b]{2}{*}{ SEM } & \multicolumn{3}{|c|}{$P$-value } \\
\hline & C & E1 & E2 & E3 & & Group & Day & Group $x$ Day \\
\hline 0 & 31.75 & 31.13 & 30.67 & 29.85 & 0.30 & 0.4963 & 0.0001 & 0.5136 \\
\hline $50^{\star}$ & 63.96 & 62.48 & 60.05 & 62.77 & 0.66 & & & \\
\hline $98^{\star \star}$ & 98.47 & 97.53 & 98.73 & 98.41 & 0.80 & & & \\
\hline
\end{tabular}

* End of first fattening stage (ST-1 feed); ${ }^{* *}$ End of second fattening stage (ST-2 feed).

C-0.3 mg/kg DM organic Se, E1-0.5 mg/kg DM inorganic Se, E2-0.5 mg/kg DM organic Se; E3-0.5 mg/kg DM organic Se+0.2\% zeolite clinoptilolite.

erythrocytes were washed three times by resuspension in $0.9 \%$ $\mathrm{NaCl}$ and centrifuged for $5 \mathrm{~min}$ at 2,000 rpm after each wash. Erythrocyte samples were frozen at $-80^{\circ} \mathrm{C}$ until analysis. For the determination of antioxidant enzyme activity in erythrocyte lysate, packed erythrocytes were hemolyzed for $10 \mathrm{~min}$ at $+4^{\circ} \mathrm{C}$ by a 4 -fold dilution with ice-cold Milli $\mathrm{Q}$ water, and the lysate was clarified by centrifugation $\left(10,000 \mathrm{~g}, 5 \mathrm{~min},+4^{\circ} \mathrm{C}\right)$ for analysis. Activity of enzymes (GSH-Px and GR) were determined by spectrophotometry in erythrocytes using the Ransel ${ }^{\circledR}$ and Glutathione Reductase ${ }^{\circledR}$ assay kits (Randox Laboratories Ltd, London, UK).

\section{Statistical Analysis}

For the evaluation of the treatment on the variability of body weight, immune parameters, oxidative parameters, and selenium concentration in blood following statistical model was used:

$$
y_{\mathrm{ijk}}=\mu+T_{\mathrm{i}}+D_{\mathrm{j}}+T_{\mathrm{i}} x D_{\mathrm{j}}+e_{\mathrm{ijk}}
$$

Where:

$\mathrm{y}_{\mathrm{ijk}}=$ estimated trait (body weight, immune parameters, oxidative parameters and selenium concentration in blood);

$\mu=$ intercept;

$\mathrm{T}_{\mathrm{i}}=$ fixed effect of treatment $\mathrm{i}$ (groups $=\mathrm{C}, \mathrm{E} 1, \mathrm{E} 2$, and E3);

$D_{j}=$ fixed effect of measurement day $j(j=0,50,71$, and 98 day of measurement);

$\mathrm{e}_{\mathrm{ijk}}=$ residual.

For the evaluation of the treatment on the variability of selenium concentration in tissues (muscle and liver) following statistical model was used:

$$
y_{\mathrm{ijk}}=\mu+T_{\mathrm{i}}+e_{\mathrm{ijk}}
$$

Where:

$$
\mathrm{y}_{\mathrm{ijk}}=\text { estimated trait (selenium concentration in tissues); }
$$

$$
\begin{aligned}
& \mu=\text { intercept; } \\
& \mathrm{T}_{\mathrm{i}}=\text { fixed effect of treatment } \mathrm{i} \text { (groups }=\mathrm{C}, \mathrm{E} 1, \mathrm{E} 2 \text {, and E3); } \\
& \mathrm{e}_{\mathrm{ijk}}=\text { residual. }
\end{aligned}
$$

The significance of the differences between the analyzed traits due to fixed effect of treatment was tested by Fischer's test at level of $P<0.05$; PROC GLM procedure in STATISTICA using TIBCO Software Inc., 2018.

\section{RESULTS}

\section{Selenium Concentration in Blood, Muscle, and Liver}

The growing pigs had similar body weights throughout the experimental period (Table 4). Se concentration in blood was higher $(P<0.05)$ in the E2 and E3 groups than in the $\mathrm{C}$ and E1 groups, and clearly depended on the Se source and quantity (Figure 1A). Higher $(P<0.05)$ Se concentrations were determined in the muscle and liver in the E2 and E3 groups and compared with those of the E1 group, and the concentrations of the E3 group were compared with those of the $\mathrm{C}$ group (Figure 1). The Se concentrations after dietary addition in the E1 group were lower $(P<0.05)$ in blood than in the E2 and E3 groups fed with the same amount of the organic source of Se (Figure 1). Pigs fed with a lower amount of organic Se (C) had a numerically higher concentration of Se compared with the E1 group (Figure 1).

\section{Recruitment of Immune Cell Subsets}

Recruitment of circulating immune cell subsets assessed by the cytometry analysis of proportions of $\mathrm{CD} 45^{+}$lymphoid cells, $\mathrm{CD}^{+}, \mathrm{CD}^{+}$, and $\mathrm{CD} 4^{+} \mathrm{CD} 8^{+} \mathrm{T}$ cells, as well as of $\mathrm{CD} 21^{+} \mathrm{B}$ cells in the peripheral blood of growing pigs fed with different Se sources for 98 days are shown in Figure 2. A higher $(P<0.05)$ proportion of total leucocytes was noted in the pigs of the E2 and E3 groups compared 
A

Blood

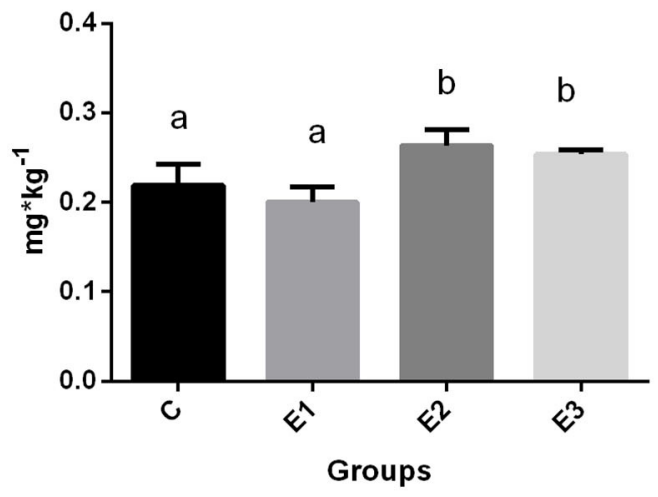

C

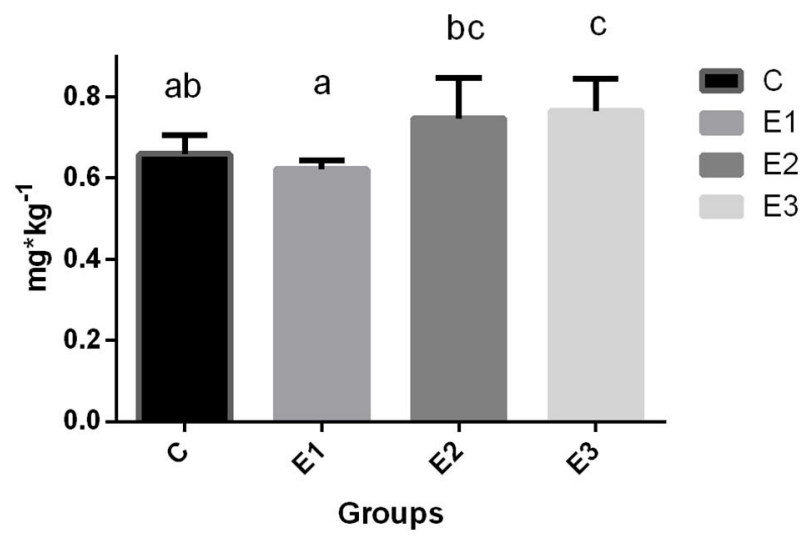

B

Muscle

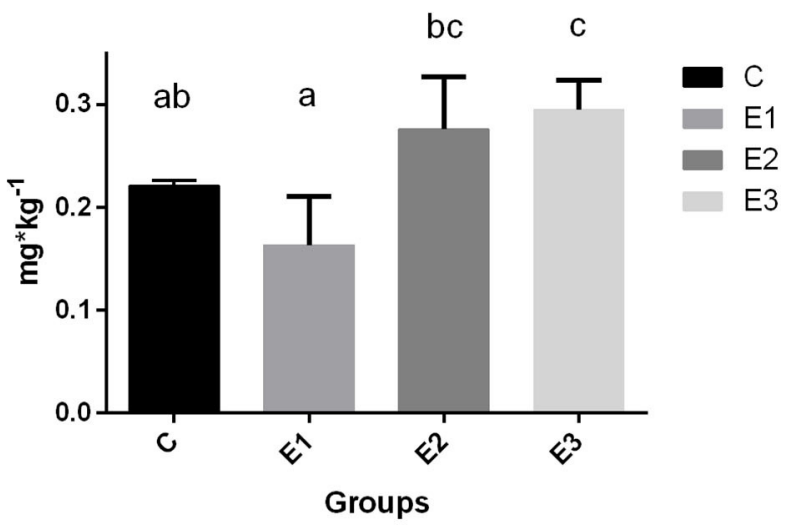

FIGURE 1 | Selenium concentration in blood (A), muscle (B), and liver (C) tissue of growing pigs fed with different sources and concentrations of selenium; C-0.3 mg/kg DM organic Se, E1-0.5 mg/kg DM inorganic Se, E2-0.5 mg/kg DM organic Se; E3-0.5 mg/kg DM organic Se+ 0.2\% zeolite clinoptilolite. Values are means \pm SEM. Bars with different superscript letters $(a, b, c)$ were different, $P<0.05$.

with groups $\mathrm{C}$ and $\mathrm{E} 1$. Interestingly, a higher $(P<0.05)$ proportion of $\mathrm{CD}^{+}$lymphocytes was observed in the pigs from the $\mathrm{E} 3$ group, while the proportion of $\mathrm{CD} 8^{+}$lymphocytes was higher $(P<0.05)$ in the E1 group. Pigs from the E2 and E3 groups had lower $(P<0.05)$ double-positive $\mathrm{CD} 4^{+} \mathrm{CD} 8^{+}$lymphocytes than pigs from the $\mathrm{C}$ and $\mathrm{E} 1$ groups. A higher $(P<0.05)$ proportion of $\mathrm{CD} 21^{+}$lymphocytes was measured in the E2 and E3 groups compared with the $\mathrm{C}$ and E1 groups.

\section{Antioxidant Enzymes Activity}

The highest $(P<0.01)$ activity of GSH-Px in pig erythrocytes in the E3 group was compared with that in the other groups. Dietary addition of higher concentrations of organic and inorganic Se increased the activity of GR in relation to the $\mathrm{C}$ group, with lower Se content in the feed.

\section{DISCUSSION}

Selenium is a crucial trace element for antioxidant and immune functions in animals and humans (25). Many studies have confirmed that organic Se acts as a real antioxidant, unlike inorganic Se, which can act as a prooxidant. Bearing in mind that many studies have proved that Se-enriched yeast is superior to inorganic sources in resorption and deposition (26-28), we used a source that contained organic Se at a concentration of $0.3 \mathrm{mg} / \mathrm{kg} \mathrm{DM}$ in a control group. The experimental groups contained higher levels of Se $(0.5 \mathrm{mg} / \mathrm{kg})$ in inorganic (E1) and organic (E2) forms, and higher levels of organic Se combined with natural zeolite clinoptilolite (E3).

Selenium deposition in muscle tissue is a good indicator of the Se status of animals (17). Organic Se has an important benefit compared with inorganic Se due to the fact that selenomethionine 


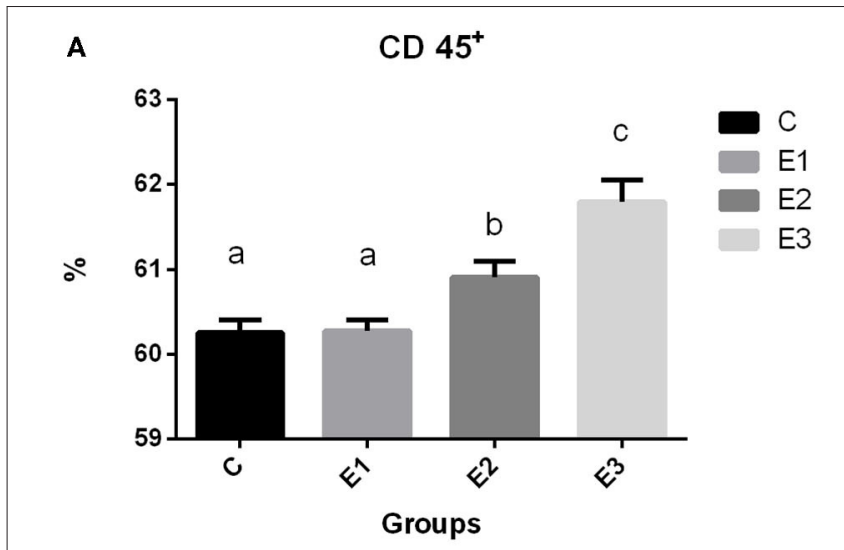

B

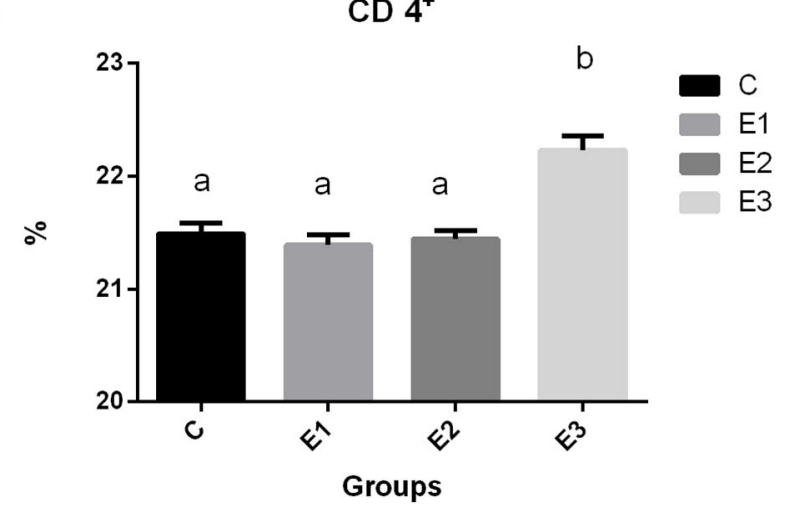

C

CD $8^{+}$

D
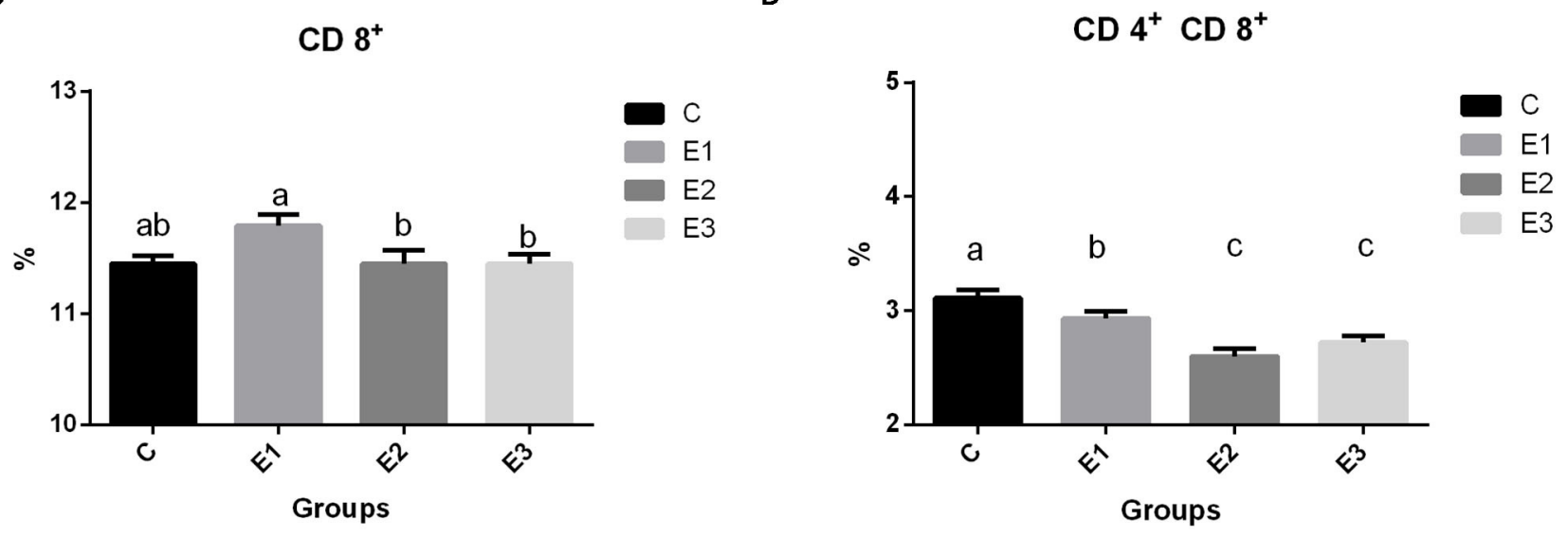

E

CD $21^{*}$

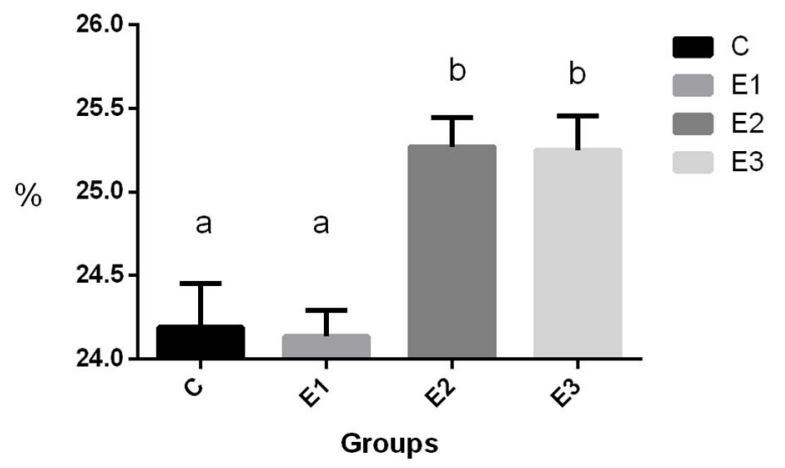

FIGURE 2 | Proportion of lymphoid cell subsets (A CD 45+, B 4+, C CD 8+, D CD 4+ CD8+, E CD 21+) in the peripheral blood of growing pigs fed with different sources and concentration of selenium. C- $0.3 \mathrm{mg} / \mathrm{kg}$ DM organic Se, E1-0.5 mg/kg DM inorganic Se, E2-0.5 mg/kg DM organic Se; E3-0.5 mg/kg DM organic $\mathrm{Se}+0.2 \%$ zeolite clinoptilolite. Values are means $\pm \mathrm{SEM}$. Bars with different superscript letters $(\mathrm{a}, \mathrm{b}, \mathrm{c})$ were different, $P<0.05$. 
A

\section{GSH-Px}

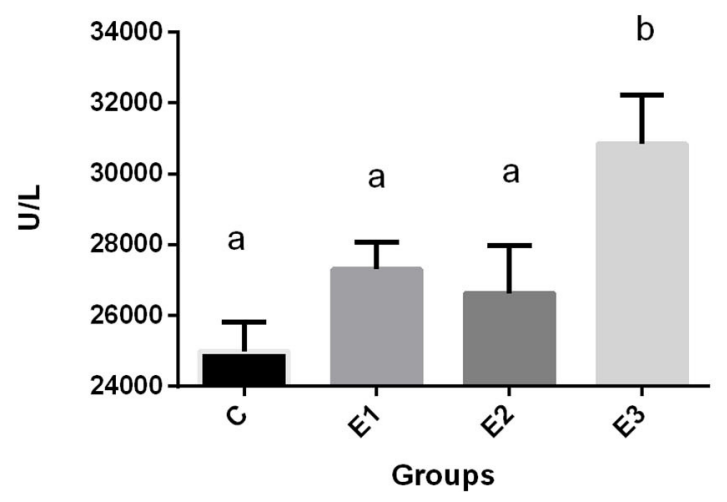

B

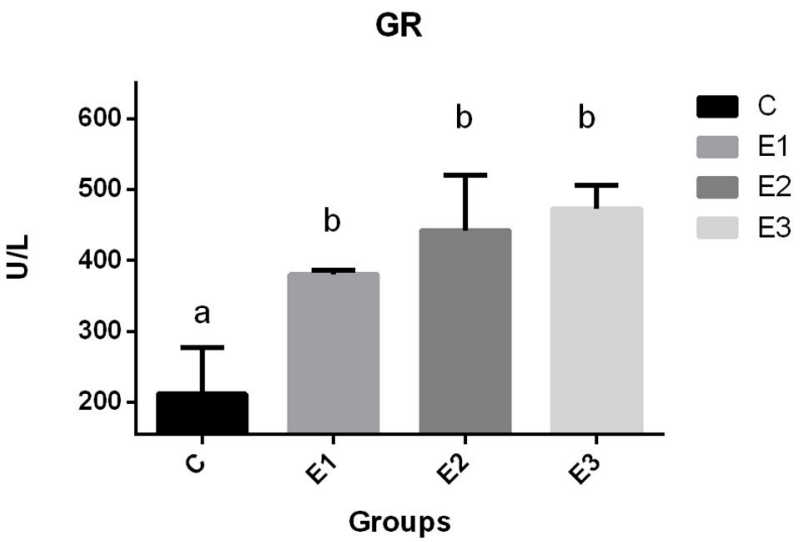

FIGURE 3 | Activities of glutathione peroxidase (A GSH-Px) and glutathione reductase (B GR) in blood of growing pigs fed with different source and concentrations of selenium. C-0.3 mg/kg DM organic Se; E1-0.5 mg/kg DM inorganic Se; E2-0.5 mg/kg DM organic Se; E3-0.5 mg/kg DM organic Se+ 0.2\% zeolite clinoptilolite.

Values are means \pm SEM. Bars with unlike superscript letters $(a, b, c)$ were different, $P<0.05$.

is utilized by the tissues as an amino acid. The Se reserve in tissues can be mobilized for subsequent selenoprotein synthesis. Selenomethionine from Se yeast is known to be the best source for increasing the level of Se and depositing Se in tissues (29). In our study, higher $(0.5 \mathrm{mg} / \mathrm{kg})$ dietary addition of Se-enriched yeast increased Se concentration in muscle and liver as compared to the addition of inorganic Se at $0.5 \mathrm{mg} / \mathrm{kg}$ (E2, E3 vs. E1). The addition of Se combined with zeolite clinoptilolite (E3) resulted in higher concentrations of Se in the muscle and liver compared with the C group. Similarly, Jiang et al. (30) found the highest deposition of Se in meat after the addition of $0.3 \mathrm{mg} / \mathrm{kg}$ Se with $1.5 \mathrm{mg}$ linseed oil. The extent of tissue deposition in liver and muscle in our study was comparable to the finding of Zhan et al. (31). Moreover, there was no difference between Se concentration in blood, muscle, and liver between basal diet according to the NRC (22) (C; $0.3 \mathrm{mg} / \mathrm{kg} \mathrm{DM})$ and inorganic Se supplementation (E1; $0.5 \mathrm{mg} / \mathrm{kg} \mathrm{DM})$, which is in agreement with the results of Mohamed et al. (32) in broiler chicken. The reason for an even higher Se concentration in the groups with zeolite addition (E3) compared with E2 is due to a positive effect of a zeolite as an adjuvant (18). Clinoptilolite is the most prevalent zeolite in the nature. Its therapeutic applications are numerous; it is used for the maintenance of body's $\mathrm{pH}$ value, reduction of free radicals, neutralization or elimination of toxins and heavy metals, the improvement of tissue oxygenations, etc. (33). Clinoptilolite is a great source of silicon in the form of orthosilicic acid which protects the body from heavy metals (34). The zeolites have a protective effect in intoxication. That effect is evidenced by researchers who observed that the clinoptilolite could have some protective effect in organophosphorus poisoning in sheep, in lead intoxication in mice, and in pigs which have received $\mathrm{CdCl} 2$ (35). The toxic elements generate reactive oxygen (ROS) or nitrogen (RNS) species that damage lipids, proteins, and deoxyribonucleic acid (DNA). Selenium forms a complex with transition metals and seleno-compounds that decrease their toxicity. Both complex formation and oxidative damages contribute to a decrease of seleno-compound concentrations like Se-methionine (36). A zeolite supplementation reduces the toxic elements concentrations by combining with them in gastrointestinal tract. In that way less complex formation and oxidative damages allows for a more Se-methionine to be deposited in tissues. The other possible way of clinoptilolite action is explained through a better Se absorption, based on an observation in Wistar rats which have received the zeolite for 34 days. Some modifications of intestinal microvilli were observed. The microvilli length was higher and the number of microvilli per square $\mu \mathrm{m}$ was higher (37), which could point to a better absorption capability. The other experiment with the newborn calves has demonstrated a better passive transfer of immunoglobulin into newborns (38).

In human medicine there are studies that support the beneficial properties of purified natural clinoptilolite as an antidiarrheic treatment (39). More recent studies performed on aerobically trained subjects, highlighted the positive effects of zeolites on intestinal wall integrity (40).

To summarize all above zeolite decreases heavy metal and mycotoxin absorption from intestines and reduces oxidative burden and at the same time improves capacity for selenium absorption which at the end result in better selenium bioavailability and higher selenium concentrations in tissues.

In our study, we found higher $(P<0.05)$ leukocyte common antigen $\left(\mathrm{CD} 45^{+}\right)$in the $\mathrm{E} 2$ and $\mathrm{E} 3$ groups than in the $\mathrm{C}$ and E1 groups, which means that $\mathrm{Se}$ and $\mathrm{Se}+$ Zeolite increase cellular immunity. Regarding the lymphocyte markers, there was a higher $(P<0.05)$ proportion of the $\mathrm{CD}^{+}$markers in the E3 group, which could be a positive effect attributed to the addition of $\mathrm{Se}+$ zeolite, because the E2 group with the same Se addition did not differ from the control group (C). Ivory et al. (41) found that Se supplementation did not enhance T-cell proliferation. 
In this case, the response was boosted by flu vaccination. In our case, the effect of increased $\mathrm{CD}^{+}{ }^{+}$cell subsets were due to the non-specific stimulation by zeolite Se+zeolite addition (Figure 2B). In contrast, higher Se supplementation increased $\mathrm{CD}^{+}$proliferation in mice at low and medium doses (42) by modulating free thiol levels and specific signaling events during $\mathrm{CD}^{+}{ }^{+}$activation. We can only speculate which dose is optimal for eliciting immune and antioxidative effects in the live organism and why in our research $\mathrm{CD}^{+}{ }^{+}$was only increased in the E3 group. Namely, the proliferation of $\mathrm{T}$ cells is related to oxidized and reduced glutathione, which is a very important molecule for cell protection against oxidative damage. As reported by Ivory et al. (41) the addition of onion (rich in flavonoids) with a low Se dose increased the granzyme and perforin content of $\mathrm{CD}^{+}$cells, while the opposite effect was observed at higher Se doses. The pigs fed with a higher concentration of organic Se in the experimental groups had a lower $(P<0.05)$ ratio of $\mathrm{CD} 8^{+}$lymphocytes when compared to the pigs fed with the same concentration of inorganic Se. This is in accordance with Taylor et al. (43) who found that a higher Se content induces a plentiful production of selenoprotein $\mathrm{P}$, which overlaps with the genes encoding several $\mathrm{T}$ cell-associated genes. Products from the cytolytic granules from $\mathrm{CD}^{+}$cells are also influenced by the dosage and form of Se; lower granzyme content with higher Se dosage has been reported by Ivory et al. (41) While Broom et al. (44) found a significant increase in $\mathrm{CD}^{+}{ }^{+}$and $\mathrm{CD}^{+}$levels and a numerical increase in $\mathrm{B}$ lymphocytes, which could be explained by the lower Se status in the patients and the immunity elicited by the poliovirus vaccine.

Dual-positive $\mathrm{T}$ lymphocytes in the peripheral circulation have been identified by researchers as part of a specific immune response, including a broad spectrum of $\mathrm{T}$ lymphocytes involved in the antiviral immune response in pigs $(45,46)$. A smaller proportion of them was found in the peripheral circulation, but it was also proven that $\mathrm{T}$ lymphocytes increased by $20 \%$ during viral infections. This cell population comprises mature effective lymphocytes specific to the repertoire of antigens encountered in the past and latent and highly persistent viral infections (47). Our results showed a lower proportion of dual positive T lymphocytes with the addition of organic Se and in combination with zeolite, which is probably due to a lack of proper challenge. Interestingly, higher dietary addition of Se elicited a share of the CD21+ lymphocytes, but only in the E2 and E3 groups, which is related to the signal transducer and set of cytokines that regulate this path of immunity. Confirmation of this could be found in Hofmann and Berry (48), who noticed that Se affects different types of immune responses in different ways, depending on the starting Se status. Avery and Hoffmann (49) concluded that the use of selenium to increase innate immunity may be enhanced when prescribed along with other nutritional antioxidants (which is zeolite in our case). Adaptive immunity is affected by selenium intake, including the activation and function of $\mathrm{T}$ and $\mathrm{B}$ cells.

Because Se is included in many selenoproteins in the body and the most commonly researched is GSH-Px, which is involved in protecting cells from oxidative damage, dietary deficiency of Se causes redistribution of intracellular Se among the selenoproteins and GSH-Px protein (50). The high dependency of GSH-Px activity on Se source and concentration in the diet has been confirmed previously by many authors $(51,52)$. A meta-analysis by Bermingham et al. (53) found a significant correlation of GSH-Px activity with Se dose and form, which is consistent with the results of Mahan et al. (54). In contrast, Oliveira et al. (16) reported a linear reduction in plasma GSH-Px activity with increased supplementation levels of organic Se, and a linear increase in hepatic GSH-Px activity with increased supplementation, regardless of the type source in post-weaning piglets. In our research, the higher concentrations of dietary organic selenium and zeolite combination increased $(P<0.05)$ GSH-Px activity in E3 group (Figure 3) when compared to the other groups. A higher GSH-GPx activity in this group is explained through a higher Se-methionine availability due to a lesser Se complex formation and lesser toxic elements ROS and RNS damage, as previously described by a higher Se tissue concentrations. An increase in dietary Se concentration, either organic or inorganic, increased GR activity in blood.

Glutathione reductase (GR) is an oxidoreductive enzyme primarily responsible for the maintenance of intracellular glutathione concentration, playing an important role in the protection of cellular components with regard to an oxidative damage, especially that of erythrocytes. It has been demonstrated that, under the conditions of an oxidative stress, the activities of the GR antioxidant enzyme have increased in serum or in erythrocytes, but, in our case, an increase in the GR activity is in connection with GSH-Px one. If selenium is sufficiently consumed in diet, the GSH-Px enzyme activity increases, and when the substrate increases, the enzyme levels increase, too, to bind the substrate, reaching the maximal steady-state rates. If the GSH-Px activity is sufficient, glutathione disulfide is produced at the levels sufficient to stimulate the GR and prevent its deactivation by the NADPH (55). Under these investigation conditions, a higher GR activity in the experimental groups signify that more glutathione was restored. Therefore, a better antioxidative defense was achieved.

Our research circumstantiates the benefits of feeding the growing pigs with slightly over the NRC recommended levels of organic selenium $(0.5 \mathrm{mg} / \mathrm{kg} \mathrm{DM})$ with the zeolite on selenium concentrations in tissues for human consumption, additionally it improves immune defense and andioxidative capacity of the growing pigs. A future research should investigate a potential of different zeolite concentration in combination with selenium on selenium tissue deposition as a benefit for humans and immune and oxidative defense as a benefit for animals.

\section{CONCLUSIONS}

The addition of organic Se is favorable to the inorganic Se in the same concentration $(0.5 \mathrm{mg} / \mathrm{kg} \mathrm{DM})$. Dietary addition of 0.5 $\mathrm{mg} / \mathrm{kg}$ DM organic Se with a zeolite addition (0.2\%) increased Se deposition in liver, muscle, and blood, compared to lower organic Se concentration $(0.3 \mathrm{mg} / \mathrm{kg})$ which has a positive implication for the pig industry as a way of producing a functional food for human benefit. A significant increase in the immune and antioxidative parameters in the group of pigs fed the combination of selenium and zeolite had the positive effect on animal health. 


\section{DATA AVAILABILITY STATEMENT}

The raw data supporting the conclusions of this article will be made available by the authors, without undue reservation.

\section{ETHICS STATEMENT}

The animal study was reviewed and approved by Bioethics Committee for Research on Animals J. J. Strossmayer University of Osijek (2158-94-02-21-02).

\section{AUTHOR CONTRIBUTIONS}

TŠ and MŠ designed this study, planned and carried out the experiments and measurements, and drafted the manuscript. MĐ carried out the measurements and analysis

\section{REFERENCES}

1. Solovyev N, Drobyshev E, Blume B, Michalke B. Selenium at the neural barriers: a review. Front Neurosci. (2021) 15:630016. doi: 10.3389/fnins.2021.630016

2. Xia Q, Yang Z, Shui Y, Liu X, Chen J, Khan S, et al. Methods of selenium application differentially modulate plant growth, selenium accumulation and speciation, protein, anthocyanins and concentrations of mineral elements in purple-grained wheat. Front Plant Sci. (2020) 11:1114. doi: 10.3389/fpls.2020.01114

3. Zhou X, Yang J, Kronzucker HJ, Shi W. Selenium biofortification and interaction with other elements in plants: a review. Front Plant Sci. (2020) 11:586421. doi: 10.3389/fpls.2020.586421

4. Ivezić V, Lončarić Z, Singh BRA, Almås ÅR. Selenium Concentration in Main Soil Types of Slavonija and Baranja County. Osijek: Poljoprivredni fakultet Sveučilišta Josipa Jurja Strossmayera u Osijeku (2013). p. 6.

5. Novoselec J, Klir Ž, Domaćinović M, Lončarić Z, Antunović Z. Biofortification of feedstuffs with microelements in animal nutrition. Poljoprivreda. (2018) 24:25-34. doi: 10.18047/poljo.24.1.4

6. Petrujkić BT, Šefer DS, Jovanović IB, Jovičin M, Janković S, Jakovljević G, Beierf RC, et al. Effects of commercial selenium products on glutathioneperoxidase activity and semen quality in stud boars. Anim Feed Sci Technol. (2014) 197:194-205. doi: 10.1016/j.anifeedsci.2014.09.001

7. Hosny NS, Hashem NM, Morsy A, Sand Abo-elezz ZR. Effects of organic selenium on the physiological response, blood metabolites, redox status, semen quality, and fertility of rabbit bucks kept under natural heat stress conditions. Front Vet Sci. (2020) 7:290. doi: 10.3389/fvets.2020.00290

8. Dalgaard TS, Briens M, Engberg RM, Lauridsen C. The influence of selenium and selenoproteins on immune responses of poultry and pigs. Anim Feed Sci Technol. (2018) 238:73-83. doi: 10.1016/j.anifeedsci.2018.01.020

9. Hawkes W, Keim N. Dietary selenium intake modulates thyroid hormone and energy metabolism in men. Nutr J. (2003) 133:3443-8. doi: 10.1093/jn/133.11.3443

10. Vukšić N, Šperanda M, Lončarić Z, Đidara M, Ludek E, Budor I. The effect of dietary selenium addition on the concentrations of heavy metals in the tissues of fallow deer (Dama dama L.) in Croatia. Environ Sci Pollut Res Int. (2018) 25:11023-33. doi: 10.1007/s11356-018-1406-7

11. Esmaeili S, Khosravi-Darani K. Selenium-enriched yeast: as selenium source for nutritional purpose. Cur Nutri Food Sci. (2014) 10:4956. doi: 10.2174/157340131001140328115753

12. Antunović Z, Klir Ž, Šperanda M, Lončarić Z, Mioč B, Kadunc NC, Samac $\mathrm{D}$, et al. Productive traits, selenium status and blood metabolic status in fattening lambs affected by selenium biofortified corn. Acta Vet Brno. (2020) 89:141-50. doi: 10.2754/avb202089020141

13. Zhang X, Tian L, Zhai S, Lin Z, Yang H, Chen J, et al. Effects of selenium-enriched yeast on performance, egg quality, antioxidant and helped to write the manuscript. ZL, VP, and MP helped with the analysis of the samples. VG has made statistical analyses. All the authors read and approved the final manuscript.

\section{FUNDING}

This research was supported by Ministry of Science, Education and Sport Republic of Croatia (Grant 079-0793448-3438; Natural immunomodulators and antioxidants in optimization of pigs' production).

\section{ACKNOWLEDGMENTS}

We would like to thank Editage (www.editage.com) for English language editing.

balance, and egg selenium content in laying ducks. Front Vet Sci. (2020) 7:591. doi: 10.3389/fvets.2020.00591

14. Calvo L, Toldrá F, Aristoy MC, López-Bote CJ, Rey AI. Effect of dietary organic selenium on muscle proteolytic activity and water-holding capacity in pork. Meat Sci. (2016) 121:1-11. doi: 10.1016/j.meatsci.2016. 05.006

15. Zavodnik LB, Shimkus A, Belyavsky VN, Voronov DV, Shimkiene A Voloshin DB. Effects of organic Se yeast administration on perinatal performance, growth efficiency and health status in pigs. Arch Zootech. (2011) 14:520-24.

16. Oliveira TFB, Bertechini AB, Philomeno R, Silva VA. Dietary levels and sources of selenium for post weaning piglets. Cienc Rural. (2017) 47:12. doi: 10.1590/0103-8478cr20170477

17. Rovers BM. Selenium deposition as a quality indicator for dietary selenium sources (2016). p. 34-6. Available online at: https://orffa.com/publications/ selenium-deposition-as-a-quality-indicator-for-dietary-selenium-sources/ (accessed June 30, 2021).

18. Kraljević Pavelić S, Simović Medica J, Gumbarević D, Filošević A, PrŽulj N, Pavelić K. Critical review on zeolite clinoptilolite safety and medical applications in vivo. Front Pharmacol. (2018) 9:1350. doi: 10.3389/fphar.2018.01350

19. Cerri G, de' Gennaro M, Bonferoni MC, Caramella C. Zeolites in biomedical application: Zn-exchanged clinoptilolite-rich rock as active carrier for antibiotics in anti-acne topical therapy. Appl Clay Sci. (2004) 27:14150. doi: 10.1016/j.clay.2004.04.004

20. Ivkovic S, Deutsch U, Silberbach A, Walraph E, Mannel M. Dietary supplementation with the tribomechanically activated zeolite clinoptilolite in immunodeficiency: effects on the immune system. Adv Therapy. (2004) 21:135-47. doi: 10.1007/BF02850340

21. Valpotic H, Terzic S, Vince S, Samardzija M, Turk R, Lackovic G, et al. In feed supplementation of clinoptilolite favourably modulates intestinal and systemic immunity and some production parameters in weaned pigs. Vet Med. (2016) 61:317-27. doi: 10.17221/175/2015-VETMED

22. NRC (National Research Council). Nutrient Requirements of Swine. 10th ed. Washington: National Academy Press (1998). p 86-7.

23. BoŽić F, Lacković G, Stokes CR, Valpotić I. Recruitment of intestinal CD45RA + and CD45RC+ cells induced by a candidate oral vaccine against porcine post-weaning colibacillosis. Vet Immunol Immunopathol. (2002) 86:137-46. doi: 10.1016/S0165-2427(02)00033-8

24. Valpotić I, Vijtiuk N, Trutin-Ostović K, Casey TA, Dean-Nystrom EA Lacković $\mathrm{G}$. Identification and distribution of $\mathrm{CD}+\mathrm{T}$ cell subsets in porcine gut following experimental infection with F4ac+ enterotoxigenic Escherichia coli (ETEC) or non-ETEC strains. Regional Immunol. (1994) 6:387-90.

25. Mrityunjaya M, Pavithra V, Neelam R, Janhavi P, Halami PM, Ravindra PV. Immune-boosting, antioxidant and anti-inflammatory food supplements targeting pathogenesis of COVID-19. Front Immunol. (2020) 11.570122 doi: $10.3389 /$ fimmu. 2020.570122 
26. Mahan DC, Kim YY. Effect of inorganic or organic selenium at two dietary levels on reproductive performance and tissue selenium concentrations in first-parity gilts and their progeny. J Anim Sci. (1996) 74:27118. doi: $10.2527 / 1996.74112711 \mathrm{x}$

27. Mahan DC, Parrett NA. Evaluating the efficacy of Se enriched yeast and inorganic selenite on tissue retention and serum glutathione peroxidase activity in grower finisher swine. J Anim Sci. (1996) 74:2967-74. doi: 10.2527/1996.74122967x

28. Mahan DC, Peters JC. Long-term effects dietary organic and inorganic selenium sources and levels on reproducing sows and their progeny. J Anim Sci. (2004) 82:1343-58. doi: 10.2527/2004.8251343x

29. Silva VA, Bertechini AG, Clemente AHS, de Freitas LFVB, Nogueira BRF, de Oliveira BL, et al. Different levels of selenomethionine on the meat quality and selenium deposition in tissue of finishing pigs. J Anim Physiol Anim Nutr. (2019) 103:1866-74. doi: 10.1111/jpn.13179

30. Jiang J, Tang X, Xue Y, Lin G, Xiong YL. Dietary linseed oil supplemented with organic selenium improved the fatty acid nutritional profile, muscular selenium deposition, water retention, and tenderness of fresh pork. Meat Sci. (2017) 131:99-106. doi: 10.1016/j.meatsci.2017.03.014

31. Zhan XA, Wang M, Zhao RQ, Li WF, Xu ZR. Effects of different selenium source on selenium distribution, loin quality and antioxidant status in finishing pigs. Anim Feed Sci Technol. (2007) 132:202-11. doi: 10.1016/j.anifeedsci.2006.03.020

32. Mohamed DA, Sazili AQ, Chwen LT, Samsudin AA. Effect of microbiotaselenoprotein on meat selenium content and meat quality of broiler chickens. Animals. (2020) 10:1-11. doi: 10.3390/ani10060981

33. Ambrozova P, Kynicky J, Urubek T, Nguyen VD. Synthesis and modification of clinoptilolite. Molecules. (2017) 22:1107. doi: 10.3390/molecules22071107

34. Martin KR. Silicon: the health benefits of a metalloid. In: Sigel A, Sigel $\mathrm{H}$, Sigel R, editors. Interrelations between Essential Metal Ions and Human Diseases. Metal Ions in Life Sciences, Vol 13. Dordrecht: Springer (2013). p. 451-73. doi: 10.1007/978-94-007-7500-8_14

35. Papaioannou D, Katsoulos PD, Karatzias H. The role of natural and synthetic zeolites as feed additives on the prevention and/or the treatament of certain farm animal diseases: a review. Micropor Mesopor Mat. (2005) 84:16170. doi: 10.1016/j.micromeso.2005.05.030

36. Arnaud J, van Dael P. Selenium interactions with other trace elements, with nutrients (and drugs) in humans. In: Michalke B, editor. Selenium. Cham: Springer (2018). p. 111-36. doi: 10.1007/978-3-319-95 390-8_22

37. Bgatova NP. Influence of long-term administration of naturally occuring sorbents on the ultrastructure of small intestine enterocyte in rats. Bull Exp Biol Med. (1998) 6:626-9. doi: 10.1007/BF02445259

38. Marc S, Kirovski D, Mircu C, Hutu I, Otava G, Paul C. Serum protein electrophoretic pattern in neonatal calves treated with clinoptilolite. Molecules. (2018) 23:1-9. doi: 10.3390/molecules230 61278

39. Rodríguez-Fuentes G, Denis AR, Álvarez MAB, Colarte AI. Antacid drug based on purified natural clinoptilolite. Micropor Mesopor Mat. (2006) 94:2007. doi: 10.1016/j.micromeso.2006.03.032

40. Lamprecht M, Bogner S, Steinbauer K, Schuetz B, Greilberger JF, Leber B, et al. Effects of zeolite supplementation on parameters of intestinal barrier integrity, inflammation, redoxbiology and performance in aerobically trained subjects. J Int Soc Sports Nutr. (2015) 12:40. doi: 10.1186/s12970-0150101-z

41. Ivory $\mathrm{K}$, Prieto E, Spinks C, Armah, CN, Goldson, et al. Selenium supplementation has beneficial and detrimental effects on immunity to influenza vaccine in older adults. Clin Nutr. (2017) 36:407-15. doi: 10.1016/j.clnu.2015. 12.003

42. Hoffmann FKW, Hashimoto AC, Shafer, L, Dow S, Berry MJ, Hoffmann PR. Dietary selenium modulates activation and differentiation of CD4 $+\mathrm{T}$ cells in mice through a mechanism involving cellular free thiols. J Nutr. (2010) 140: 1155-61. doi: 10.3945/jn.109.120725
43. Taylor EW. Selenium and cellular immunity. Evidence that selenoproteins may be encoded in the +1 reading frame overlapping the human CD4, CD8, and HLA-DR genes. Biol Trace Elem Res. (1995) 49:8595. doi: 10.1007/BF02788958

44. Broome CS, McArdle F, Kyle JAM, Andrews F, Lowe NM, Hart CA, et al An increase in selenium intake improves immune function and poliovirus handling in adults with marginal selenium status. J Clin Nutr. (2004) 80:15462 doi: 10.1093/ajcn/80.1.154

45. Zuckermann FA, Husmann RJ. Functional and phenotypic analysis of porcine peripheral blood CD4/CD8 double-positive T cells. Immun. (1996) 87:500-12.

46. Hernandez J, Garfias Y, Nieto A, Mercado C, Montano LF, Zenteno, et al. Comparative evaluation of the CD4+CD8+ and CD4+CD8- lymphocytes in the immune response to porcine rubulavirus. Vet Immunol Immunopathol. (2001) 79:249-59. doi: 10.1016/S0165-2427(01)00259-8

47. Nascimbeni M, Shin EC, Chiriboga L, Kleiner DE, Rehermann B. Peripheral CD4/CD8 Double-Positive $\mathrm{T}$ cells are differentiated effector memory cells with antiviral functions. Blood. (2004) 104:478-86. doi: 10.1182/blood-2003-12-4395

48. Hoffmann PR, Berry MJ. The influence of selenium on immune responses. Mol Nutr Food Res. (2008) 52:1273-80. doi: 10.1002/mnfr.200700330

49. Avery JC, Hoffmann PR. Selenium, selenoproteins, and immunity. Nutr. (2018) 10:1203. doi: 10.3390/nu10091203

50. Hesketh J. Nutrigenomics and selenium: gene expression patterns, physiological targets, and genetics. Annu Rev Nutr. (2008) 28:157-77. doi: 10.1146/annurev.nutr.28.061807.155446

51. Colakoglu HE, Yazlik MO, Kaya U, Colakoglu EC, Kurt S, Oz B, et al. MDA and GSH-Px activity in transition dairy cows under seasonal variations and their relationship with reproductive performance. J Vet Res. (2017) 61:497502. doi: 10.1515/jvetres-2017-0067

52. Juniper DT, Rymer C, Briens M. Bioefficacy of hydroxy-selenomethionine as a selenium supplement in pregnant dairy heifers and on the selenium status of their calves. J Dairy Sci. (2019) 102:7000-10. doi: 10.3168/jds.2018-16065

53. Bermingham EN, Hesketh JE, Sinclair BR, Koolaard JP, Roy NC. Seleniumenriched foods are more effective at increasing glutathione peroxidase (GPx) activity compared with selenomethionine: a meta-analysis. Nutr. (2014) 6:4002-31. doi: 10.3390/nu6104002

54. Mahan DC, Cline TR, Richert B. Effects of dietary levels of seleniumenriched yeast and sodium selenite as selenium sources fed to growingfinishing pigs on performance, tissue selenium, serum gluthatione peroxidase activity, carcass characteristics and loin quality. J Anim Sci. (1999) 77:21729. doi: $10.2527 / 1999.7782172 x$

55. Upton JR, Edens FW, Ferket PR. The effects of dietary oxidized fat and selenium source on performance, glutathione peroxidase, and glutathione reductase activity in broiler chickens. J Appl Poult Res. (2009) 18:193202. doi: 10.3382 /japr.2008-00019

Conflict of Interest: The authors declare that the research was conducted in the absence of any commercial or financial relationships that could be construed as a potential conflict of interest.

Publisher's Note: All claims expressed in this article are solely those of the authors and do not necessarily represent those of their affiliated organizations, or those of the publisher, the editors and the reviewers. Any product that may be evaluated in this article, or claim that may be made by its manufacturer, is not guaranteed or endorsed by the publisher.

Copyright (c) 2021 Šperanda, Pavić, Lončarić, Šperanda, Popović, Gantner and Didara. This is an open-access article distributed under the terms of the Creative Commons Attribution License (CC BY). The use, distribution or reproduction in other forums is permitted, provided the original author(s) and the copyright owner(s) are credited and that the original publication in this journal is cited, in accordance with accepted academic practice. No use, distribution or reproduction is permitted which does not comply with these terms. 